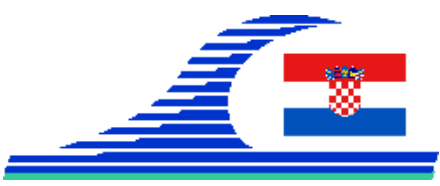

Conférence Méditerranéenne Côtière et Maritime

EDITION 4, SPLIT, CROATIA (2017)

Coastal and Maritime Mediterranean Conference

Disponible en ligne - http://www.paralia.fr - Available online

\title{
Effect of offshore winds and storm waves on the efficiency of beach nourishment behind detached breakwaters, the Barcarès beach, France
}

\section{Yann BALOUIN ${ }^{1}$, Eric PALVADEAU ${ }^{1}$, Ywenn DE LA TORRE ${ }^{2}$, Damien DAILLOUX ${ }^{3}$, Hugo CHRISTMANN ${ }^{1}$}

1. BRGM, Direction régionale Occitanie, 1039, rue de Pinville, 34000 Montpellier, France.

y.balouin@brgm.fr

2. BRGM Direction Régionale Guadeloupe, Parc d’activité de Colin, La Lézarde, 97170 Petit-Bourg, France.

y.delatorre@brgm.fr

3. CASAGEC Ingénierie, Parc d’activité 18, rue Maryse Bastié, Zone de Maignon, 64600 Anglet, France.

dailloux@casagec.fr

\begin{abstract}
:
In 2014, 3 detached breakwaters were implemented at the wave-dominated beach of Le Barcarès, S France, to fight against erosion and submersion hazards. Additionally, beach nourishments are undertaken every summer. Daily video images from Oct 2014 to July 2016 covering an alongshore distance of $1.6 \mathrm{~km}$ are used to analyse the response of the shoreline to the structure implementation and to the main forcing factors (SE storms and Tramontane winds). Results show that the breakwaters clearly modified the shoreline shaped by the formation of salient. However, in contrast with the adjacent southern beach, the shoreline is not stabilised and shows rapid short-term variations as well as a great seasonal variability. Nourishment efficiency appears to be clearly linked with the occurrence of storm events that generate a loss of sediment northwards and tramontane winds that favours a southwards sediment transport and an increase of sediment volume in the area.
\end{abstract}

Keywords: Video monitoring, Efficiency of protection works, Nourishments, Salient.

\section{Introduction}

The Barcarès beach is an open microtidal beach facing the Mediterranean Sea. This area suffers from a sand deficit induced by the harbor of Port-Barcarès that traps the sediment drift from the south. The site is south-north oriented and is concerned by marine storms from SE and E with significant wave heights over $3 \mathrm{~m}$. The wind regime is characterized by the predominance of an offshore wind, the Tramontane, from NW 
Mediterranean rocky coasts:

Features, processes, evolution and problems

that can reach velocities over $100 \mathrm{~km} / \mathrm{h}$. To protect the habitations, 3 detached breakwaters were deployed at the end of summer 2014 in the continuity of 3 existing ones. Moreover, annual beach nourishments are undertaken behind these new breakwaters before the summer season. To monitor shoreline evolution and the effects of these breakwaters, a video system was deployed in October 2014 (http://obscat.fr/webcam). A rotating camera permits to survey the entire protected area.

\section{Methods}

A video monitoring system consisting in 1 rotating camera mounted on a15-m high building has been collecting data since October 2014. 5-min averaged images of the 5 cameras views are combined and transformed to real-world plan view images on a $1 \mathrm{x} 1$ $\mathrm{m}$ grid from October 2014 to July 2016. The rectified images extend $600 \mathrm{~m}$ in the crossshore and $1.6 \mathrm{~km}$ in the alongshore direction (figure 1). In the studied area in front the station locations, the maximum pixel footprint is $0.5 \mathrm{~m}$ in the cross-shore and alongshore directions. These accuracies decrease to about 1-2 $\mathrm{m}$ at the northern end of the field site. Additional shorelines are analyzed before and after storm events and/or strong winds events.

Furthermore, topography and bathymetry survey are undertaken every 6 months since 2013 within the Catalan Sandy Coast Observatory (ObsCat). Wave conditions are registered offshore at Leucate Wave Buoy (DREAL Occitanie) and winds at Le Barcarès are provided by the Synops network.

\section{Results}

\subsection{Hydrodynamics}

The site of Le Barcarès is characterized by a moderate wave climate. The prevailing wave direction is from ESE. During the monitoring period (see figure 2), an important event was registered in November 2014 with Hs reaching $4.5 \mathrm{~m}$. This winter was however quite calm. The following winter was more energetic with 5 storm events overpassing $3 \mathrm{~m}$ in Hs. Moreover, North winds velocities were important during the period from January to May 2016 with wind gusts sometimes overpassing $120 \mathrm{~km} / \mathrm{h}$. 


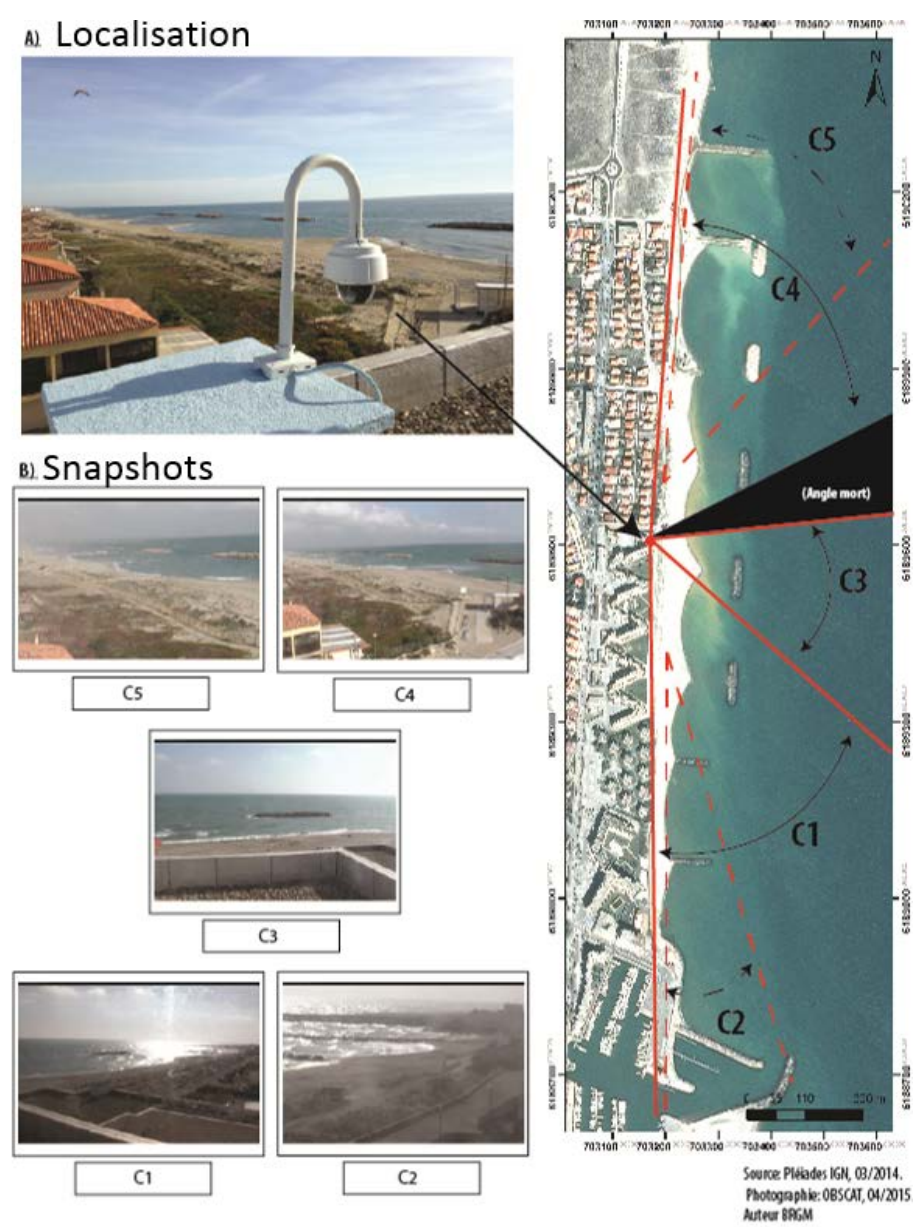

Figure 1. Setup of the video monitoring system and location of the 5 camera views.

\subsection{Shoreline evolution}

Analysis of around 100 shoreline positions permits to define the general evolution of the beach during the monitored period. Beach width variability is much higher on the northern area where the new equilibrium position after the implementation of the breakwaters is still not reached. Shoreline position amplitude reaches $60 \mathrm{~m}$ at the salients and $40 \mathrm{~m}$ in between. Southwards, where the breakwaters are older, the maximum seasonal variability is around $25 \mathrm{~m}$. This important amplitude evidences the high seasonal variability but also points on the high capacity of the beach to recover after the winter period. Net shoreline retreat is also contrasted between northern and southern area. After nourishment, the northern part shows a quite important retreat, while the southern area remains stable.

However, this evolution is not linear, and the temporal evolution of shoreline position indicates the important role of marine storms and tramontane wind events on the evolution of this coast.

In the northern area (blue line of figure 2), a progressive advance in the shoreline position is observed. This advance results from the beach nourishments undertaken in 
Mediterranean rocky coasts:

Features, processes, evolution and problems

June 2015 and 2016. These nourishments induced an advance of $20 \mathrm{~m}$ in 2015 and 10$15 \mathrm{~m}$ in 2016. Storm events have resulted in a moderate shoreline retreat except the storm of September 2015 that yielded a retreat of around $10 \mathrm{~m}$. For all these events, beach recovery was rapid and efficient, and shoreline position was recovered after a few days. In between the nourishments (from June 2015 to the beginning of 2016), a progressive shoreline retreat was observed. This apparently results both from the erosional tendency and from the sand transport from the bays to the salients.

In the central part of the site (red line), shoreline evolution is more constant. A progressive advance is observed, although rapid retreats during storms. This part of the beach not concerned by the nourishments probably benefits from southwards sand transport during tramontane events.

In the southern part between the groins (green line), an advance was observed between October 2014 to April 2015, and then begins to retreat.

Evolution of the salients appears to be clearly linked to the wave and wind conditions. Marine storms induce a northwards migration of their crest, and a decrease of their amplitude.

\subsection{Nourishment}

Two beach nourishments have been undertaken during the monitoring period in June 2015 and 2016. The concerned area is the northern part of the site where the new breakwaters were implemented. Replenishment strategy was to fill the bay in-between the salients to obtain a quite linear shoreline and the maximum beach width. As observed on figure 2, these nourishments induced a rapid advance in the shoreline position $(\sim 20 \mathrm{~m})$. A few days after the works, the shoreline retreated rapidly $(\sim 6 \mathrm{~m})$, traducing the expected sand transport from the bays to the crest of the salients, without loss of nourished sand volume. A seasonal shoreline retreat/advance was then observed, the spring 2016 shoreline position being more or less the same as June 2015. This seasonal evolution is clearly related with the occurrence of storms and tramontane wind events. Storms induced a decrease in sand volume in the area, by increasing the northwards longshore drift while Tramontane winds generate a southwards sand transport. This phenomenon is clearly observed on the N-S position of the salient (figure 2c).

\section{Concluding remarks}

Video Monitoring at Le Barcarès beach provides useful information on the dynamics of this area where an important management program was implemented within the last years. The beach presents a contrasted evolution: quite stable in the south, and very dynamic in the north. The northern area presents an important seasonal evolution, rapid retreat during storms and a good resilience. Despite repeated nourishments, the tombolos behind the breakwaters are not well-formed, and their efficiency in stabilizing 
Mediterranean rocky coasts:

Features, processes, evolution and problems

the beach is not clear yet. Variations in beach width and sediment volume seem to be mainly driven by the occurrence of storm from SE and Tramontane winds from the north. The first one generates a longshore transport towards the updrift northern coast, decreasing the sediment budget of the area; the second generates a southwards sand transport favoring an increase of the sand volume that compensates the sediment starvation usually observed.

All this information on short to medium term time scale provides an important insight in evolution processes that clearly influences the efficiency of protection works. The monitoring is on-going to better understand the effects of protection of this city front.

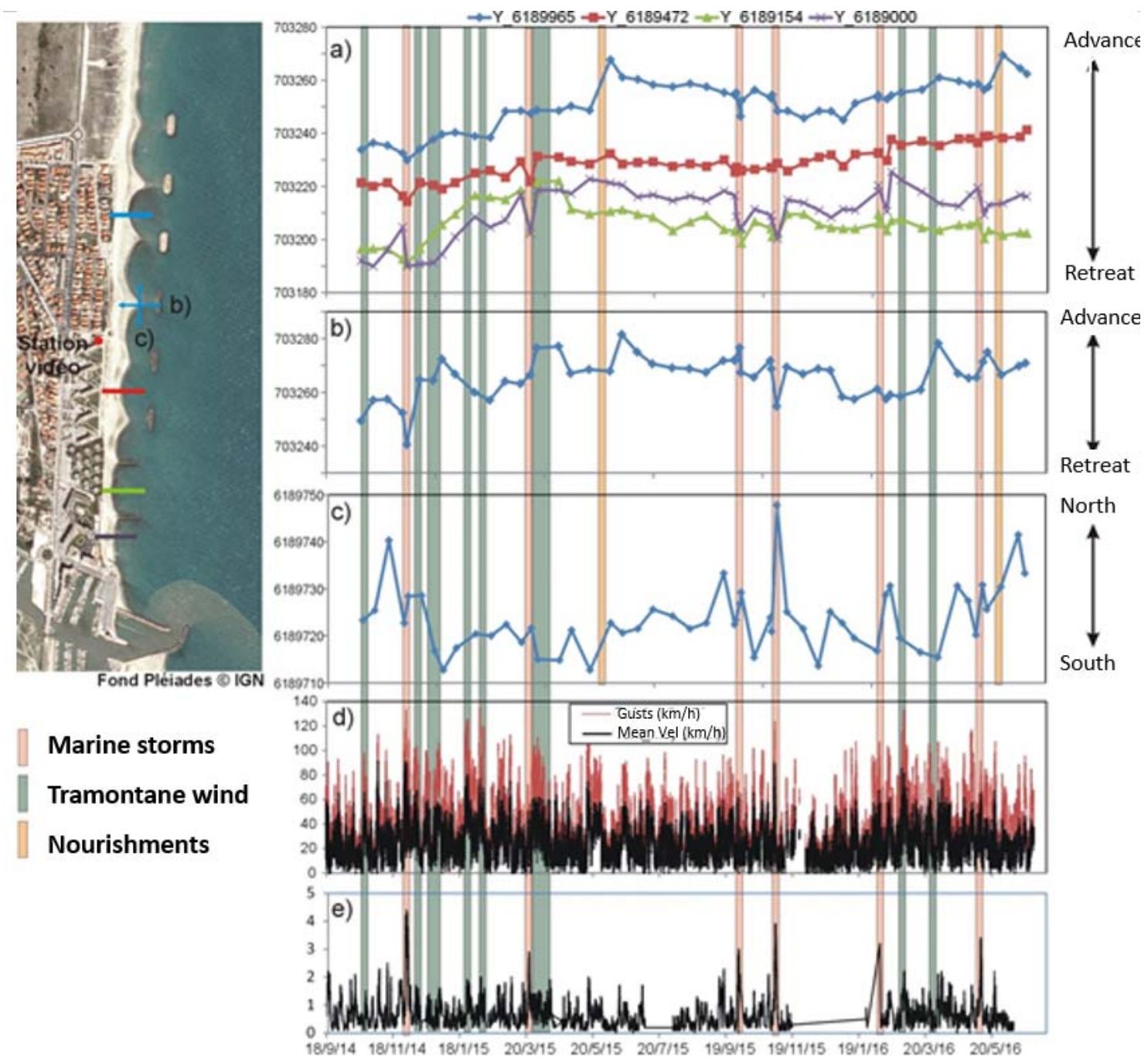

Figure 2. Video monitoring of Le Barcarès beach (left) and Evolution of the salient with waves and wind: a) cross-shore mobility of the shoreline on several location of the studied area (see location on the left), b) Cross-shore mobility of the salient, c) longshore mobility of the salients, $d$ ) wind velocities (mean and gusts in $\mathrm{km} / \mathrm{h}$ ) and e) significant wave high at Leucate wave buoy (m). 
Mediterranean rocky coasts:

Features, processes, evolution and problems 